MYKOL ROMERIO
UNIVERITEIAS

\title{
SOCIALINIO TEISINGUMO SUVOKIMAS: PILIEČIŲ IR VARTOTOJŲ VERTYBINIAI SKIRTUMAI
}

\author{
Vitalija Rudzkienė, Miglè Eleonora Černikovaitė \\ Mykolo Romerio universiteto Ekonomikos ir finansų valdymo fakulteto \\ Ekonomikos ir verslo institutas \\ Ateities g. 20, LT-08303 Vilnius \\ Telefonas (+370 5)2714547 \\ Elektroninis paštas vital@mruni.eu;miglec@mruni.eu
}

Pateikta 2013 m. sausio 15 d., parengta spausdinti 2013 m. rugpjūčio 10 d.

doi:10.13165/SMS-13-5-3-05

Anotacija. Sunkumai, su kuriais susiduria išsivysčiusios ir, juo labiau, besivystančios valstybès palaikydamos socialinès apsaugos sistemas, kelia klausima dél visuomenès paramos ir požiürio i socialini teisinguma, kuris sudaro šiu sistemu pagrindą. Nors socialine tikslo vertybe laikoma darni, socialiai teisinga visuomene, skirtingu ideologiju, išsivystymo lygio ir atskiru visuomenès grupiu samprata, koks tai turètu büti visuomenès modelis, ženkliai skiriasi. Iš viso socialiniu grupiu spektro didžiausi ideologiniai skirtumai išryškèja dvieju kraštutiniu visuomenés grupiu - pilieciu ir vartotoju - vertybiu sistemose. Nors pastaraisiais metais vertybiu tyrimams skiriamas didelis demesys, socialinio teisingumo vertybes, ju konceptualizacija, vertybiu formavimasis ir dominavimas atskiruose socialiniuose sluoksniuose, vertybiu. evoliucija dar menkai išnagrinèti. Straipsnyje socialinio teisingumo vertybès nagrinejamos is dvieju, ideologiškai prieštaringu visuomenés grupiu-vartotoju ir piliečiu, poziciju. Remiantis teorine analize išskirta teorine principu ir prielaidu aibe, kurios pagrindu sukonstruota logine struktüra ir sudarytas teorinis tyrimo modelis. Remiantis reprezentatyvios apklausos rezultatais patikrintos teorines hipotezès ir išnagrinèti vertybiu skirtumai. Empirinio tyrimo rezultatai patvirtino šešias iš devyniu suformuluotu teoriniu hipotezių. Tyrimo rezultatai leido išskirti büdingus kolektyvisto ir individualisto požiūrio i socialini teisingumą skirtumus ir sudaryti ju savybiu rinkinius. 
Parengta vykdant LMT finansuojama projekta SIN-12005 „Piliečiu ir vartotoju socialinio-ekonominio teisingumo suvokimo formavimo gaires".

Reikšminiai žodžiai: socialinis teisingumas, socialinès vertybès, visuomenès grupès, vartojai, piliečiai.

\section{Ivadas}

Socialiniu-istoriniu pagrindu susiformavusios teisingumo paradigmos kartu suformavo ir platų šiuolaikinių socialinių teisingumo teorijų spektrą, kur esama ịvairių sampratų ir apibrèžimų, nagrinejjančių socialinị teisingumą filosofiniais, moraliniais, psichologiniais, politiniais, ekonominiais, teisiniais aspektais. Publikacijų gausa šia tema parodo socialinio teisingumo svarbą visuomenei. Daug mokslininkų ir tyrejų domejjosi ir nagrinėjo šią sritị (John Rawls, Robert Nozick, Amartya Sen, Friedrich von Hayek, Martha Nussbaum, Brian Barry, Richard A. Posner, Marc Fleurbaey ir daug kitu).

Literatūroje, skirtoje socialinio teisingumo analizei, nagrinejjama keletas socialinio teisingumo modelių. Geriausiai žinomas modelis - vieno faktoriaus, kurio pagrindą sudaro skirstomasis teisingumas. Šis modelis dažnai nagrinejjamas ir geriausiai žinomas.

Kitą, dviejų faktorių, modelį sudaro skirstomasis ir procedūrinis socialinis teisingumas. Trečiajį, trijų faktorių, modelį sudaro skirstomasis, procedūrinis ir sąveikos faktoriai. Sąveikos faktorių išskyrus ị dvi dalis - tarpasmeninį teisingumą ir informacinị teisingumą, buvo sudarytas keturiu faktorių modelis. Atlikti empiriniai tyrimai parodé, kad šis modelis tinka duomenų analizei ${ }^{1}$.

Socialiniam teisingumui artima socialinès darnos samprata. Socialinė darna glaudžiai susijusi su socialinėmis problemomis ir dialogo tarp visuomenès ir politikos formavimu. Tai neatsiejamas darnos elementas, kadangi darni plètra negali būti be darnios visuomenès dalyvavimo ${ }^{2}$. Tokiu būdu socialinès darnos ir socialinio teisingumo tikslai sutampa.

Nors socialine tikslo vertybe laikoma tobula, socialiai teisinga visuomene, skirtingų ideologijų, išsivystymo lygio ir atskirų visuomenès grupių samprata, koks tai turètų būti visuomenès modelis, ryškiai skiriasi ${ }^{3},{ }^{4}$. Iš viso socialinių grupių spektro didžiausi ideologiniai skirtumai išryškejja dviejų kraštutinių visuomenės grupių - piliečių ir vartotojų - vertybių sistemose, nagrinëjamose tolesniuose skyriuose.

1 Colquitt, J. A.; Conlon, D. E.; Wesson, M. J.; Porter, Ch. O. L. H.; Ng, K. Yee. Justice at the millennium: A meta-analytic review of 25 years of organizational justice research. Journal of Applied Psychology. 2001,86 (3): 425-445.

2 Burinskiene, M.; Rudzkiene, V. Assessment of sustainable development in transition. Ekologija. 2007, 53: 27-33.

3 Dromantienè, L. Socialinès Europos kūrimas. Vilnius: Mykolo Romerio universitetas, 2008.

4 Bernotas, D.; Guogis, A. Development of social security in Lithuania: achievements and drawbacks. Forum Bosnae. Sarajevo: Međunarodni forum Bosna. 2012, 55: 150-165. 
Ankstesnių laikų filosofai ir ekonomistai turejo nuomonę, kad kiekvienas individas turi savo unikalią ir pastovią prioritetų aibę. Tačiau pastarujjų metų tyrimai šios nuomonės nepatvirtino, priešingai, buvo atskleista, kad preferencijos, kurias individai išreiškia ir taiko, kai kuriais aspektais yra institucinio konteksto funkcija ${ }^{5}$. Todèl preferencijos, taip pat jas suponuojančios vertybès ir ịsitikinimai lengviau suprantami ir analizuojami, kai i jas žvelgiama ne kaip ị unikalias, o kaip ị būdingas tam tikram sluoksniui ar grupei.

Reikia pažymėti, kad, kaip teigia Feldmanas ${ }^{6}$, socialinių vertybių konceptualizacija, kaip vertybès formuojasi ir palaikomos, beveik nėra išnagrinėta. Socialinès vertybès taikomos arba analizuojant jų veikimo pasekmes, arba, mažose imtyse, kaip vertybiniai prioritetai. Taigi, daugelis tyrimų fokusuojasi i individualaus lygio vertybes, kurios yra dažniausiai aprašomojo pobūdžio, o apibendrintos mokslinės pozicijos, kaip bendrosios vertybès formuojasi ir vystosi, kol kas nèra sukurta.

Straipsnio tikslas - išnagrinėti ideologiškai prieštaringų dviejų visuomenės grupių, vartotojų ir piliečių, suvokiamo socialinio teisingumo vertybių prioritetus, patikrinti teorinius modelius ir prielaidas, ištirti, kaip individo socialinis statusas veikia jo pažiūrą i socialinio teisingumo igyvendinimą visuomenèje ir pačius socialinio teisingumo principus.

Analitinè dalis remiasi sudarytu teoriniu tyrimo modeliu, kuri pasitelkus analizuojami reprezentatyvios apklausos, kurią $2013 \mathrm{~m}$. balandžio 10-14 d. atliko visuomenės nuomonès ir rinkos tyrimų centras ,Vilmorus“, rezultatai.

Tyrimo metodai. Teorinè dalis remiasi lyginamaja mokslinès literatūros analize, statistiniais koreliacinès, suderinamumo ir vienfaktorinès dispersinès analizès metodais.

\section{Socialinio teisingumo suvokimo koncepcija}

Termino „suvokimas“ reikšmè skiriasi priklausomai nuo mokslo srities. Suvokimui (percepcijai) dažnai suteikiama prasmė, kuri naudojama kognityvinèje psichologijoje, kur suvokimas suprantamas kaip aibe procesų, per kuriuos mes suteikiame prasmę pojūčiams, kuriuos gauname iš aplinkos dirgiklių?

Šiame darbe „,Suvokimas“ vartojamas kita prasme nei kognityvinëje psichologijoje. Socialinėje psichologijoje suvokimas suprantamas kaip mokslas apie tai, kokị poveiki žmonių mintys, jausmai ir elgesys turi kitiems ir yra veikiami kitų žmonių ${ }^{8}$. Situacijos teisingumo ar neteisingumo suvokimas apima atpažinimą arba įvertinimą (neišreikštini). Tai, savo ruožtu, paremta individualiomis ir visuomeninėmis vertybèmis, t. y. ką individas supranta esant teisingą ar neteisingą, vertą ar nevertą. Vertybės, kuriomis indivi-

5 Frohlich, N.; Oppenheimer, J. A. Values, Policies, and Citizen Competence: An Experimental Perspective. Citizen Competence and Democratic Institutions (Elkin, S. L.; Soltan, K. E. eds.). The Pennsylvania State Univ. Press, 1999, p. 161-187.

6 Feldman, S. A Conflicted Public? Equality, fairness, and Redistribution [interaktyvus]. 2003 [žiūrèta $2013-$ 01-10]. <http://www.princeton.edu/csdp/events/Inequality2003/feldman.pdf>.

7 Stenberg, R. Cognitive Psychology. Fort Worth: Harcourt Brace College Publishers, 1999.

8 Hogg, M. A.; Vaughan, G. M. Social Psychology. Harlow: Prentice Hall, 2002. 
das remiasi vertindamas situacijos teisingumą, turi daug apibrèžimų. Vienas iš dažniausiai taikomų yra Rokeacho9: ,ilgalaikis tikejimas(-ai), kad konkretus elgesio büdas ar siekiamas egzistavimo būvis yra asmeniškai arba socialiai prïmtinesnis nei priešingas ar atvirkščias elgesio modelis ar siekiamas egzistavimo būvis (vertimas autoriu)“. Kitaip sakant, tai normatyvinès teisingumo idejos, t. y. to, kas yra svarbu ar verta didelio dèmesio, idèjos.

Teisingumo suvokimą lemia ne tik vertybès, bet ir kitos konstrukcijos: įsitikinimai, išgyvenimas (patyrimas), nuomonè, supratimas (1 pav.). Visi šie terminai susiję su kognityviniu procesu, su individo pastangomis suteikti prasmę, įvertinti situaciją, su kuria jie susidūrè, ir pritaikyti socialines normas, todèl vertybès glaudžiai siejasi su socialiniu normu koncepcija. Normos yra paplitęs elgesys, pagrịstas įsitikinimu, kad kaip tik toks elgesys ir privalo būti, tik taip vertybès gali būti realizuojamos. Normos dažnai yra konkretesnès nei vertybès. Pavyzdžiui, vertybė ,ekonominė nepriklausomybe்“ gali būti susieta su dviem normomis: sunkus darbas ir finansinè nepriklausomybe் $\dot{e}^{10}$. Jei vertybè „lygybé“, tai norma - ,turto perskirstymas“.

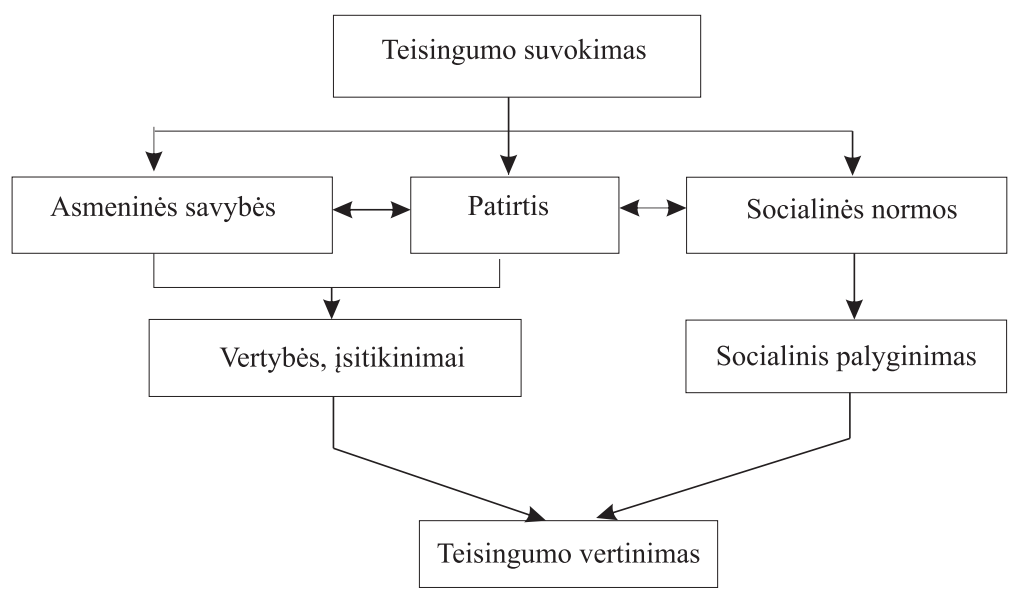

1 pav. Konceptualus socialinio teisingumo suvokimo modelis

Visi kognityviniai teisingumo suvokimo elementai (1 pav.) yra susiję tarpusavyje. Egzistuojančio teisingumo vertinimas priklauso nuo spragos tarp suvokimo ir vertybių bei įsitikinimų dydžio. Kuo didesnis skirtumas tarp to, kaip žmonès suvokia ir vertina esamą teisingumą, ir jų teisingumo idèjų, tuo griežtesni tampa esamo teisingumo vertinimai. Kaip rodo patirtis, žmonėms yra sunku gyventi, kai jų esamo pasaulio suvokimas nesutampa su jų samprata, koks jis turètų būti. Todèl jie gali adaptuoti savo normatyvines nuostatas taip, kad jos ,tiktų“ suvokimui. Kitaip tariant, pagal tai, ką žmonès suvokia kaip „esamą“, jie gali koreguoti tai, kas „turi būti“"11.

9 Rokeach, M. The Nature of Human Values. New York: Free Press, 1973.

10 Suhay, E. A. Group Influence ans American Ideals: How Social Identity and Emotrion Shape Our Political Values and Attitudes. Doctoral Dissertation. University of Michigan, Ann Arbor, MI, 2008.

11 Marshall, G.; Swift, A.; Routh, D.; Burgoyne, C. What Is ans What Ought to Be: Popular Beliefs About Distributive Justice in Thirteen Countries. European Sociological Review. 1999, 15: 349-367. 
Kaip matyti iš sudaryto konceptualaus teisingumo suvokimo modelio, socialinio teisingumo vertybių ir ịsitikinimų ịtaka yra daugialype ir sudètinga. Dẻl savo sudėtingumo socialinio teisingumo koncepcija reikalauja atskleisti žmonių prioritetus ir pasirinkimą, kurio negalima gauti vien iš teorinių samprotavimų. Taigi, vertybių ir įsitikinimų rinkinius ir jų poveikị kiekvienai visuomenès grupei galima įvertinti tik atlikus išsamius empirinius tyrimus.

\section{Vertybių koncepcijos}

Manoma, kad vertybės yra vienos iš svarbiausių veiksnių, lemiančių individų ir visuomenių elgesio skirtumus ${ }^{12}$. Svarbiausia socialine tikslo vertybe laikoma tobula, socialiai teisinga visuomenè. Savo ruožtu, priklausomai nuo to, kaip šio tikslo siekiama, skiriamos socialinès moralinès, socialinès politinės ir socialinès teisinės vertybiu grupès ${ }^{13}$.

Kaip matyti iš konceptualus socialinio teisingumo suvokimo modelio, vertybės yra vienas iš pamatinių socialinio teisingumo suvokimo elementų. Nors pastaraisiais dešimtmečiais daugelis mokslininkų ir tarptautinių organizacijų vertybėms skiria daug dèmesio, tiksliai išvardinti specifines, tarp jų ir socialines politines bei socialinio teisingumo, vertybes nèra trivialu. Vertybių koncepcijas ir jų raidą analizavę mokslininkai skirtingai ịvardija prioritetines vertybes. Pavyzdžiui, I. Kantas pagrindinèmis socialinèmis vertybėmis laikè laisvę, lygybę, asmenybès savarankiškumą. Tuo tarpu A. Maslowas pabrèžia asmeninių vertybių svarbą ${ }^{14}$.

Keičiantis socialinei-demografinei aplinkai (išsilavinimui, informuotumui ir pan.), keičiasi ir žmonių preferencijos. Nepaisant to, vertės teoretikai randa esminių skirtumų tarp vartotojo ir piliečiu interesų. Vartotojo interesas rodo gerovès preferenciją, kurios individas siekia sau, tuo tarpu piliečio preferencija apima visą visuomenę. Vartotojo preferencijos yra gana stabilios, o piliečio priklauso nuo konkrečios situacijos.

Daugelis šiuolaikinių išsivysčiusių visuomenių prioritetu linkę laikyti individualistini „Vakarų šalių“ modelị, kuriame akcentuojamos asmeninès ambicijos, žmogaus (individo) teisès ir laisvès. Manoma, kad šios „Vakarų vertybès“ yra būtina ekonominès pažangos prielaida ${ }^{15},{ }^{16}$. Dažnai teigiama, kad pagrindinis ekonomiškai išsivysčiusių šalių vertybių komponentas yra suformuotas protestantizmo etikos, kuri sudaro „Vakarų

12 Schwartz, S. H. Value orientations: Measurement, antecedents and consequences across nations. Jowell, R.; Roberts, C.; Fitzgerald, R.; Eva, G. (Eds.) Measuring attitudes cross-nationally - lessons from the European Social Survey. London: Sage, 2006.

13 Juknevičius, S. Skirtingumo dimensijos: Lietuvos gyventojų vertybès europiniame kontekste. Vilnius: Gervelè, 2002.

14 Maslow, A. Psichologiniai duomenys ir vertybių problema. Gério kontūrai. XX a. užsienio etika. Vilnius: Mintis, 1989.

15 Weber, M. The Protestant ethic and the spirit of capitalism. New York: Charles Scribner's Sons. (Original work published as two separate essays, 1904-1905).

16 Abbott, L. F. Theories of industrial modernization and enterprise development: A review of the social science literature. New Ypok: Industrial Systems research Publications, 1983. 
vertybių“ašị. Protestantizmo etika siejama su individualumo, asketizmo ir sunkaus darbo idealais, kuriems šiuolaikinėse industrinėse visuomenėse suteikiami ryškūs prioritetai.

Individualistinès protestantizmo vertybès dažniau siejamos su sparčiu ekonomikos vystymu, manant, kad kolektyvizmas, visuotinė lygybė ir sukurtų gèrybių perskirstymas trukdo sparčiam ekonomikos vystymuisi. Vis dèlto kiti tyrèjai ${ }^{17}$ pastebi, kad toks individualizmo iškèlimas skatina viską nustelbiantị vartotojiškumą ir komercinị požiūrị ì socialinị gyvenimą ir gamtinę aplinką.

Daug mokslininkų jau prieš kelis dešimtmečius pradejjo kalbėti apie tai, jog vartotojiška rinka, vyraujanti pastaruosius dešimtmečius, buvo pavojingai iškreipta ekonominès naudos link, taigi pilietị šiuolaikinèje visuomenèje pakeitè vartotoju. Būtent vartojimas tapo veiksniu, nulemiančiu individo socialinị statusą, saviraišką ir netgi savimonę. Tačiau vartojimas tik dar labiau skatina socialinę diferenciaciją ir atotrūkị tarp turtingai ir skurdžiai gyvenančių vartotojų ${ }^{18}$.

\section{Pilietiškumo koncepcijos}

Vartotojo samprata paprastai nesukelia daug diskusijų. Pasak prancūzų filosofo J. Baudrillard'o, pats vartotojas, vedamas savo poreikių patenkinimo ir siekdamas sukurti sėkmingo žmogaus tapatybę, gyvena tam, kad vartotų. Vartojimas pats savaime tapo veiksniu, nulemiančiu individo socialinị statusą, saviraišką ir netgi savimonę. Tuo tarpu pilietiškumo koncepcijų analizei skirta daugybe studijų, kur pateikiama nemažai pilietiškumo sampratų ${ }^{19},{ }^{20},{ }^{21},{ }^{22}$ ir kt. Pilietybès prasminès konstrukcijos pagrindą sudaro socialinio susitarimo procesas tarp valstybès ir plačiosios visuomenès. Autonomijos ribos, savęs reguliavimo laipsnis ir paklusimas visuomenès galiai lemia šị kultūriškai apribotą susitarimo procesą. Sociologijoje pateikiamas platus pilietiškumo atributų spektras. Šiais atributais galima sudaryti daugybę pilietiškumo šablonų nuo individualizmo iki bendruomeniškumo. Tai parodo, kad nėra vienos visiems priimtinos pilietiškumo sampratos.

Prie įtakingiausių pilietiškumo koncepcijų priskiriama koncepcija, išaugusi iš liberalios demokratinès tradicijos. Šios koncepcijos pagrindą sudaro individualybès, lygiateisiškumo ir individualios autonomijos idejos. Pilietis apibrěžiamas kaip juridinis asmuo su teisiškai nustatytomis civilinėmis, politinėmis ir socialinėmis teisėmis ${ }^{23}$. Nepaisant to, kad pilietiškumo funkcija yra didinti solidarumą, pilietines dorybes ir ịsi-

17 Kovel, J. The Enemy of Nature: The End of Capitalism or the End of the World?, Second Editon, 2007.

18 Baudrillard, J. Vartotojų visuomene. Kaunas: Kitos knygos, 2010.

19 Mann, M. Ruling class strategies and citizenship. Sociology.1987, 21 (3): 339-354.

20 Turner, B. S. Citizenship studies: a general theory. Citizenship studies. 1997, 1 (1): 5-18.

21 Turner, B. S. Civility, civil sphere and citizenship: solidarity versus the enclave society. Citizenship studies. 2008, 12 (2): 177-184.

22 Cogan, J. D.; Grossman, D.; Lui , M. Citizenship: The democratic imagination in a global local context. Social Education. 2000, 64 (1): 48-52.

23 Cohen, J. Changing paradigms of citizenship and the exclusiveness of the demos. International Sociology. 1999, 14 (3): 245-268. 
pareigojimus, liberalai tipiškai mato pilietybę kaip teisių rinkinį, kuris sudaro sąlygas puikiam individualumo vystymui, be jokių trukdžių iš valdžios ar kitų individų pusės. Taigi, pagal šią koncepciją pilietis yra juridinis asmuo, su teisiškai apibrèžtomis teisèmis ir kuris gali laisvai vystyti savo individualybę nustatytose ribose.

Žvelgiant istoriškai, T. H. Marshallas ${ }^{24}$ apibendrino pilietiškumo koncepciją nuo iki tol egzistavusios siauresnès politinès sampratos, kuri buvo grindžiama ryšiu tarp piliečio ir valstybės, iki platesnio sociologinio požiūrio, kur akcentuojamas ryšys tarp individo ir visuomenès ${ }^{25}$. Marshallo konceptuali pilietiškumo sistema apima tris sritis: civilinę, politinę ir socialinę, taip pat institucijas, kurios realizuoja šias sritis. M. Mannas išplète pilietiškumo sampratą, ịvesdamas kelias industrinių valstybių pilietiškumo vystymosi kryptis: liberalią, reformistinę, autoritarinę monarchinę, fašistinę ir socialistinę. B. S. Turner manymu, šios pilietiškumo kryptys yra skirtingo istorinio vystymosi pasekmė ir būtent skirtinga istorinė aplinka suformuoja skirtingą pilietiškumo topologiją. Jo tvirtinimu, piliečiai kontroliuoja individų ir grupių galimybes naudotis ekonominiais (būsto, sveikatos, pajamų ir užimtumo), kultūriniais (išsilavinimas, religija, kalba) ir politiniais (balsavimas ir dalyvavimas politiniame gyvenime) ištekliais. Būtent šis pilietiškumo santykis su ištekliais ir sudaro šiuolaikinès visuomenès pilietiškumo konfliktų pagrindą.

Pilietiškumas vienu ar kitu pavidalu siejamas su gerovès valstybe ir socialinio aprūpinimo sistema. Vieną iš geriausiai žinomų gerovès valstybių tipologijų $1990 \mathrm{~m}$. pasiūlè G. Esping-Andersenas ${ }^{26}$. Pagal šią tipologiją skiriami trys pagrindiniai šiuolaikinès gerovès valstybès makrolygio modeliai: socialdemokratinis (social-democratic), konservatyvus-korporatyvinis (conservative-corporate) ir liberalus (liberal) ${ }^{27}$ kurių kiekvienam būdingi tam tikri vertybių prioritetai, taikomos socialinės rūpybos sistemos, socialinès politikos organizavimo būdai. Kiekvienas modelis pasižymi jam būdinga politine ir socialine ideologija: liberalus modelis akcentuoja individualizmo ideologiją, konservatyvus-korporatyvinis - askriptyvizmo (angl. ascribe - priskirti), socialdemokratinis - egalitarizmo ${ }^{28}$. Dalis žmonių yra apolitiški, neturi politinės orientacijos ir nedalyvauja rinkimuose. Kaip rodo tyrimai, tokie žmonės dažnai yra fatalistai. Jie neturi savo visuomenès idealo arba netiki šio idealo igyvendinimo galimybe.

Išskirti gerovès valstybių tipai siejasi su skirtingomis pilietiškumo suvokimo koncepcijomis. Literatūros analizė atskleidžia dvi plačias nagrinėjamas pilietiškumo kryptis $^{29}$ :

- $\quad$ pilietiškumas kaip teisinis statusas,

- $\quad$ pilietiškumas kaip pageidaujama veikla.

24 Marshall, T. H. Class, citizenship, and social development; essays. Westport, Conn., Greenwood Press, 1973.

25 Steenberg, B. van ed. The condition of citizenship. London: Sage Publications, 1994.

26 Esping-Andersen, G. Three Worlds of Welfare Capitalism. Cambridge; Polity Press, 1990.

27 Ibid.

28 Bodo, Lippl. Justice Ideologies, Income-Justice, and the Welfare State: A Comparison of Justice Ideologies and the Perceived Justice of Income in the United States, West Germany, and the Netherlands (ISJP-Arbeitsbericht No. 47). Berlin: Humboldt-Universitaet, 1998.

29 Oldfield, A. Citizenship and Community: Civic Republican and the Modern World. London, Routledge, 1990. 
Šių koncepcijų skirtumus išryškina daugelis autorių. Viena iš tokių skirtingų piliečio traktavimo priežasčių, manoma, kyla dèl valstybès identiteto problemos. Jeigu ị valstybę žvelgiama kaip teisinị ir politinị darinị (ką palaiko ir formuoja JT), tai toks darinys labai skiriasi nuo tautinès valstybès, paremtos istoriniu ir kultūriniu identitetu ${ }^{30}$. Pagal Faulksą ${ }^{31}$, liberalaus piliečio supratimas susiduria su esmine problema: šis požiūris yra vidujai prieštaringas. Šiuo požiūriu pilietis turi būti ir individualus (ypatingas), ir visuomeninis.

Pagal individualų liberalų modeli piliečiui numatomos minimalios pareigos: mokèti mokesčius, gerbti kitų piliečių teises, esant grèsmei ginti valstybę (Oldfield). Liberalus modelis neteigia „gero gyvenimo“ koncepcijos. Jo idejja - sukurti tokią pilietiškumo igyvendinimo sistemą, kur pilietis galètų rinktis alternatyvas pagal savo „gero gyvenimo" sampratą 32 .

Pilietiškumas kaip pageidautina veikla yra kitame politinio spektro gale ir akcentuoja kolektyvinę (bendruomeninę) pilietiškumo sampratą, kai individai demonstruoja savo pilietiškumą per atsidavimą veiklai. Pagal šią koncepciją kiekvienas pilietis yra atsakingas savo politinei bendruomenei ir tik per šios atsakomybès ịgyvendinimą veiklos pavidalu pilietis tampa ir lieka piliečiu. Taigi, toks pilietiškumas yra daugiau viešas nei privatus. Pagal šį modeli piliečiui reikalinga veikimo erdvė, kur žmonès galėtų vykdyti savo veiklą ir užsiimti pilietine praktika.

\section{Individualizmas ir kolektyvizmas}

Dèl prieštaringų ir ideologiškai skirtingais principais grindžiamų pilietiškumo krypčių sudaryti vieną apibendrinantị pilietiškumo modeli nèra įmanoma. Juo labiau, kad pilietiškumo kryptis, akcentuojanti individualizmą, iš esmès priartejo prie rinkos ir vartotojo. Pavyzdžiui, Faulksas teises, kurias liberalai sutapatina su pilietybe (ir demokratija) ir kurios apima teisę kaupti turtą ir ji vartoti, ginti savo interesus bei teises rinkoje, vadina „rinkos teisèmis“ (,teisę kaupti ir vartoti turta kaip asmuo mano esant reikalinga, ginti savo interesus rinkoje ir rinktis iš plataus paslangu tiekejju spektro (vertimas autoriu)". Liberalios piliečio sampratos koncepcijos kritikai teigia, kad nereikètų akcentuoti individualių teisių ir pilietybès kaip jų rẻmimo būdo. Komunos šalininkai teigia, kad esminè pilietiškumo sampratos ideja yra ịsipareigojimai bendrijai. Visas kitas teises apibrěžia politine bendrija. Tačiau tokiu atveju iš piliečio teisių dingsta mažumų problemos, kurioms kyla grèsmè būti išskirtoms iš bendrijos.

Dèl piliečio sąvokos daugiaprasmiškumo teoriniu lygmeniu dažniausiai nagrinèjama ne piliečio ir vartotojo, o individualizmo ir bendruomenès grupių (kolektyvizmo)

30 Sor-Hoon, Tan. Challenging Citizenship- Group Membership And Cultural Identity In A Global Age. Ashgate Pub Ltd, 2005.

31 Faulks, K. Citizenship. London: Routledge, 2000.

32 Gilbert, N. Transformation of the Welfare State: The Silent Surrender of Public Responsibility. New York: Oxford University Press, 2002. 
vizija $^{33}$. Dèl šios priežasties nagrinëjant piliečio ir vartotojo socialinio teisingumo suvokimą toliau išskirtos dvi piliečius ir vartotojus atitinkančios koncepcijos: individualistai ir kolektyvistai. Individualizmas ir kolektyvizmas dažniausiai nagrinėjami kultūriniu požiūriu, o šias kryptis apibūdina bendros vertybès, įsitikinimai, normos ir vaidmenys. Kolektyvizmas siejamas su tendencija besąlygiškai save priskirti grupei ir pripažinti grupès interesų viršenybę. Iš kolektyvisto tikimasi, kad jis savo interesus pajungs grupès interesams ir kolektyviniam gériui. Be to, kadangi kolektyvistai apibrèžia save kaip savo grupės dalị, jie kaip didžiausią vertybę mato tarpasmeninius ryšius ir grupès harmoniją ${ }^{34}$. Kolektyvistų supratimą ir elgesị formuoja su jų grupe susijusi informacija.

Tuo tarpu individualistai yra labiausiai susirūpinę savo, kaip individo, interesais. Individualistas pirmiausia siekia asmeninių rezultatų ir naudos, nekreipdamas dèmesio i grupinius interesus. Pavyzdžiui, individualistui būtų būdingas klausimas „o man kas iš to?". Individualistai mato save kaip nepriklausomas būtybes ir nepriklausomybę vertina labiau nei savo grupès vertybes ar ryšius su kitais ${ }^{33}$. Apibendrinant galima pasakyti, kad individualistų motyvacija yra asmeninė nauda ir nepriklausomybè. Individualistų vertybės, emocijos, įsitikinimai, elgesys yra formuojami išskiriant sau reikšmingą informaciją. Atlikti tyrimai, pavyzdžiui ${ }^{35}$, atskleidžia skirtingą individualistų ir kolektyvistų informacijos suvokimo sampratą. Analizuodami informaciją ir vertindami rezultatų naudą jie sudeda skirtingus akcentus. Socialiniuose ryšiuose, kaip ir kitur, pagrindinis individualistų interesas yra asmeninis. Taigi, situaciją jie linkę vertinti teigiamai, jeigu ji tenkina jų asmeninius interesus, visiškai neatsižvelgdami ị tai, kad ji neutrali ar žalinga kolektyvui, kuriam jie priklauso. Atitinkamai, kolektyvistai rezultatus vertina kaip palankius, jeigu jie naudingi jų grupei, net jeigu jie neutralūs ar žalingi jiems patiems. Manoma, kad skirtingai suvokiamos individualistų ir kolektyvistų socialinio teisingumo vertybės yra suponuotos skirtingų kultūrinių vertybių ${ }^{36}$.

\section{Teorinès tyrimo hipotezès}

Kadangi, kaip buvo minėta, su socialiniu teisingumu susijusių atributų aibė yra labai plati, yra sukurta nemažai teorinių modelių. Šiuos modelius patvirtina ir empiriniai tyrimai. Pavyzdžiui, remdamasis JAV vykdytų apklausų rezultatais, Feldmanas parodè kad, kai svarstoma apie resursų paskirstymą visuomeneje, taikomi du santykinai nepriklausomi principai: mikroteisingumo ir makroteisingumo. Mikrolygmens principas yra pagristas tikèjimu rinkos galia ir atpildu pagal nuopelnus, tuo tarpu makrolygmens

33 Sor-Hoon, Tan. Challenging Citizenship- Group Membership And Cultural Identity In A Global Age. Ashgate Pub Ltd, 2005.

34 Markus, H. R.; Kitayama, S. Culture and the self: Implications for cognition, emotion, and motivation. Psychological Review. 1991, 98: 224-253.

35 Earlye, P. C.; Gibson, C. B. Taking stock in our progress on individualism-collectivism: 100 years of solidarity and community. Jounal of Management. 1998, 24: 265-304.

36 Choi, J. Outcome Favorability, Procedures, and Individualism-Collectivism in Procedural Justice perceptions. Seoul Journal of business. 2003, 9 (1): 1-26. 
principas atspindi didesnès lygybės poreikį. Praktiškai skirtumas tarp mikro- ir makroteisingumo atitinka rinkos teisinguma ir politini teisinguma.

Hipoteze $H_{1}$ : individualistai pasitiki rinka ir jos teikiamomis galimybėmis (mikrolygmuo), o kolektyvistai daugiau pasitiki valdžia ir makrolygmens perskirstymu.

Hipoteze $\mathrm{H}_{2}$ : vartotojai, kurie naudojasi rinkos teikiamomis galimybėmis (priklausomai nuo jų materialinės padèties), prioritetą teikia išteklių paskirstymui ,pagal nuopelnus".

Suskilusios sąmonès teorija teigia, kad individų sąmonėje gali nekonfliktuodamos arba mažai konfliktuodamos kartu egzistuoti dvi ideologijos. Pirmoji yra dominuojanti ideologija (kurios pagrindinis vaidmuo yra įteisinti aukštesniųų visuomenès sluoksnių ir grupių privilegijuotą statusą), kuri labai aktyviai skleidžiama per žiniasklaidos priemones, švietimo sistemą ir oficialią kultūrą. Antroji ideologija susiformuoja dedant varginančias kasdienines pastangas dèl ribotų išteklių, dèl kurių ir pradeda kilti abejonès dèl esamos išteklių paskirstymo sistemos, įteisinančios aukštesnių socialinių grupių privilegijas, teisètumo. Šios normos paprasčiausiai užima skirtingus individo sąmonès „,segmentus ${ }^{637}$. Apibendrinus teorinius samprotavimus galima suformuluoti šią hipotezę:

Hipoteze $H_{3}$ : vyresni žmonès, kurių sąmonèje stipriau suformuota egalitarinè paskirstymo sistema, mažai pasitiki rinka.

Materialinę padètị nèra paprasta tiksliai išmatuoti, tačiau ịvertinant kolektyvizmo ideologiją galima manyti, kad:

Hipoteze $H_{4}$ : žmonių pajamos turi priklausyti nuo to, kiek jie sukuria naudos visuomenei.

Dominuojančios ideologijos hipotezè teigia, kad visuomenëje vyraujanti ideologija suformuoja individo vertybes ir požiūrị i skirstomaji teisingumą. Kadangi individo pozicija socialinèje sistemoje siejasi su resursų kontrolès galimybe, tai aukštesnių socialinių sluoksnių individai turètų išreikšti mažesnę paramą lygiaviniam paskirstymui ir paskirstymui pagal poreikị.

Hipoteze $H_{5}$ : aukštesnių socialinių sluoksnių individai visuomenę mato labiau harmoningą nei žemesnių sluoksnių ir mažiau remia lygiavinį paskirstymą ir paskirstymą pagal poreikį.

Šviečiamoji ideologija remiasi prielaida, kad igiję išsilavinimą (ypač aukštaji) žmonès geriau supranta Vakarų vertybes, tarp jų ir lygybès principą ir vaidmenį, kuri šis principas vaidina demokratinèje sistemoje.

Hipoteze $H_{6}$ : labiau išsilavinę asmenys pasisako už mažesnę turtinę diferenciaciją (daugiau pilietiškumo)

Lyčiu ideologija. Kadangi moterys dèl asmeninių savybių daugiau reiškiasi globos ir rūpybos srityse, jos linkusios daugiau nei vyrai taikyti ,rūpybos principą“, akcentuojant paskirstymą pagal poreikius.

Hipoteze $H_{7}$ : moterys daugiau remia paskirstymą ,pagal poreikic" nei vyrai.

Procedūrinis teisingumas. Galimybè dalyvauti sprendimo priėmimo procese yra viena iš plačiausiai tiriamų procedūrinių charakteristikų. Dalyvavimas yra procesas, 
kuriame ịtaka yra padalinama tarp individų, kurie yra hierarchiškai nelygūs. Toks dalyvavimas dar vadinamas proceso kontrole ar balso efektu. Grupinis ar individualistinis informacijos priėmimas, susijęs su skirtingu informacijos suvokimo procesu, turi įtakos individualistų ir kolektyvistų elgesiui ir supratimui.

Hipoteze $H_{8}$ : individualistai nori turèti individualią kontrolę sprendimo prièmimui.

Hipoteze $H_{9}$ : jeigu individuali kolektyvisto nuomonè gali prieštarauti grupès tikslams, jos neišsako.

Suformuluotų hipotezių pagrindu buvo sudarytas teorinis tyrimo modelis (2 pav.).

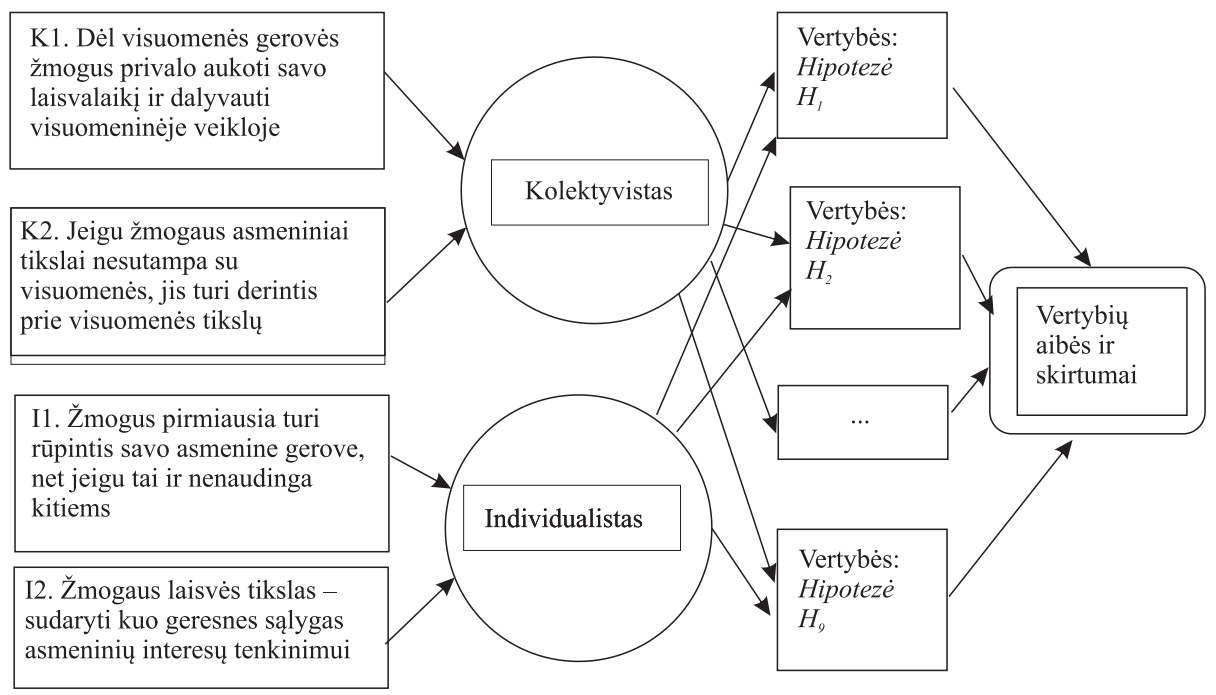

2 pav. Teorinis tyrimo modelis

\section{Tyrimo metodologija}

Klausimynas, duomenys ir populiacija. Rengiantis tyrimui buvo sudarytas pradinis klausimynas ir atliktas bandomasis tyrimas. Bandomajame tyrime dalyvavo 238 respondentai. Bandomojo tyrimo duomenų analizė buvo atlikta pritaikius daugiamačių skalių metodą, faktorinès ir vienfaktorinès dispersinès analizès ANOVA metodus. Šiais metodais buvo atrinkti teiginiai, kurie geriausiai diskriminuoja heterogeninę respondentų aibę pagal individualistinę ir kolektyvinę pozicijas.

Reprezentatyvią apklausą $2013 \mathrm{~m}$. balandžio 10-14 d. atliko visuomenès nuomonès ir rinkos tyrimų centras ,Vilmorus“. Jos metu buvo apklausta 1050 Lietuvos gyventojų. Atsakymai buvo matuojami nominaline skale ir penkių balų standartine Likerto skale.

Analizés metodai. Tyrimas remiasi sudėtinga ryšių tarp abstrakčių, teorinių koncepcijų ir empirinių rodiklių analize. Tam tikslui buvo pasitelkti statistiniai analizès metodai, tokie kaip ranginė koreliacija, suderinamumo kriterijai ir vienfaktorinè dispersinè analizè. Šie metodai yra ypač tinkami nustatyti kompleksinių endogeninių kintamųų ryšius. 


\section{Tyrimo rezultatai}

Rezultatu apžvalga. Prieš pateikiant daugiamatès statistikos tyrimo rezultatus, bendrai apžvelgsime tyrimo rezultatus socialinio teisingumo vertinimo plotmėje. Didžiausio pritarimo susilaukè teiginys „Skirtumas tarp to, ką uždirba Lietuvoje turtingi žmonès ir eiliniai piliečiai, yra per daug didelis“, kuriam pritare (,sutinku“ ir „visiškai sutinku“) 84 proc. respondentų. Antroje vietoje pagal palankumą teiginys „Visuomenejje sukurtas gèrybes reikia perskirstyti taip, kad būtu patenkinti pagrindiniai poreikiai ne tik gerai uždirbančių, bet ir visų kitų žmonių“, kuriam pritare 69,8 proc. visų apklaustujų Šie rezultatai panašūs ị kitose šalyse vykdytų tyrimų rezultatus ${ }^{38}$.

Prasčiausiai buvo įvertintas sąveikos teisingumas. Su teiginiu „Manau, kad pas mus vienodai mandagiai ir pagarbiai elgiamasi su visais žmonėmis, nepriklausomai nuo jų padèties visuomenèje“" sutiko / visiškai sutiko tik 9 proc. respondentų. Tyrimas patvirtino informacinio teisingumo reikšmę. Teiginiui „Žmonès nebūtinai turi žinoti visą informaciją, nes ji reikalinga tik tiems, kurie priima sprendimus“ pritare tik 21,5 proc. apklaustujų.

Sprendžiant iš K1 ir K2 teiginių (K1: „Dèl visuomenès gerovès žmogus privalo aukoti savo laisvalaiki ir dalyvauti visuomeninejje veikloje“ ir K2: „Jeigu žmogaus asmeniniai tikslai nesutampa su visuomenès, jis turi derintis prie visuomenès tikslų“) kolektyvistų visuomeneje yra apie 30 proc., kadangi su K1 teiginiu sutiko („sutinku / visiškai sutinku“") 30,9 proc., o su K2 - 29,9 proc. respondentų. Individualistų yra daugiau: I1 ir I2 teiginiams pritare (,sutinku / visiškai sutinku“) atitinkamai 45,9 ir 51,5 proc. apklaustujų.

Vertinant priežastis, dèl kurių Lietuvoje žmonès tampa turtingi, net 45,1 proc. atsakè, kad dèl „Nesąžiningų susitarimų ir korupcijos“, o 18,5 proc. - „Déka palankaus likimo ir jiems tinkamai susiklosčiusių aplinkybių“. Tik 2,5 proc. respondentų nuomone, turtingais tampama „Dèl gero išsilavinimo“.

Nors kolektyvistus apibūdinantys teiginiai K1 ir K2 yra panašūs ir tik papildo vienas kitą (tai patvirtina ir Spearmano koreliacijos koeficientas, $r_{\mathrm{Al}, \mathrm{A} 2}=0,42$, stebimasis reikšmingumo lygmuo $\left.p=1 \cdot 10^{-6}\right)$, jie nèra vienareikšmiški ir todèl kolektyvistų charakterizavimui buvo pasirinktas K2 teiginys (,Jeigu žmogaus asmeniniai tikslai nesutampa su visuomenès, jis turi derintis prie visuomenès tikslų"). Individualistus apibūdinančių teiginių I1 ir I2 koreliacija irgi yra reikšminga $\left(r_{\mathrm{A} 1, \mathrm{~A} 2}=0,56, p=1 \cdot 10^{-8}\right)$. Individualistų apibūdinimui buvo pasirinktas teiginys I1 (,Žmogus pirmiausia turi rūpintis savo asmenine gerove, net jeigu tai ir nenaudinga kitiems"). Teiginiai K2 ir I1 buvo pasirinkti todèl, kad jie yra griežtesni ir sulaukẻ kiek mažiau pritarimo nei jiems artimi teiginiai $\mathrm{K} 1$ ir $\mathrm{I} 2$.

Teoriniu hipoteziu tikrinimas. Pagal K2 ir I1 teiginius buvo sudarytos kolektyvistų ir individualistų aibès pagal taisyklę: jeigu K2 suteikta didesnė vertė nei I1, respondentas priskirtas kolektyvistams, jei priešingai - individualistams, jeigu vienodai - tarpinei

38 Lewin-Epstein, N.; Kaplan, A.; Levanon, A. Distributive Justice and Attitudes Toward the Welfare State. Social Justice Research. 2003, 16 (1). 
aibei. Taip buvo sudarytos trys aibės, kur išskirti 466 (44,4 proc.) individualistai, 215 (20,5 proc.) kolektyvistų ir 369 (35,1 proc.) tarpinių respondentų.

Suformuotos trys aibės buvo panaudotos teorinių hipotezių tikrinimui. Hipotezių tikrinimo rezultatai pateikti 1 lentelèje.

1 lentele. Teorinių hipotezių tikrinimo rezultatai

\begin{tabular}{|c|c|}
\hline Hipotezè & Išvada \\
\hline $\begin{array}{l}\text { Hipoteze } H_{l} \text { : kolektyvistai daugiau pasiti- } \\
\text { ki valdžia ir makro- lygmens perskirstymu } \\
\text { (makro- lygmuo), o individualistai pasitiki } \\
\text { rinka ir jos teikiamomis galimybemis } \\
\text { (mikro-lygmuo) }\end{array}$ & $\begin{array}{l}\text { Hipotezè pasitvirtino. Su teiginiu „Žmonès priva- } \\
\text { lo pasitikèti valdžia ir reikšti jai pagarbą“ sutiko } \\
44,2 \text { proc. kolektyvistų ir } 27 \text { proc. individualis- } \\
\text { tų. Pagal Chi-kvadratu kriterijų, individualistų, } \\
\text { kolektyvistų ir neapsisprendusių asmenų pajamų } \\
\text { skirtumai nereikšmingi }\left(c 2=48,3 ; p=1 \cdot 10^{-8}\right)\end{array}$ \\
\hline $\begin{array}{l}\text { Hipoteze } H_{2} \text { : vartotojai, kurie naudojasi } \\
\text { rinkos teikiamomis galimybėmis (turi ge- } \\
\text { resnę materialinę padètị), prioritetą teikia } \\
\text { resursų paskirstymui „pagal nuopelnus“ }\end{array}$ & $\begin{array}{l}\text { Hipotezė nepasitvirtino. Tarp individualistų, ko- } \\
\text { lektyvistų ir tarpinių asmenų reikšmingų pajamų } \\
\text { skirtumų nenustatyta (c2 } 2=9,2, p=0,06)\end{array}$ \\
\hline $\begin{array}{l}\text { Hipotezè } H_{3} \text { : vyresni žmonès, kurių } \\
\text { sąmonejje stipriau suformuota egalitarinè } \\
\text { paskirstymo sistema, mažai pasitiki rinka }\end{array}$ & $\begin{array}{l}\text { Hipotezė pasitvirtino. Kolektyvistų ir tarpinių } \\
\text { asmenų amžiaus skirtumai nereikšmingi (vidurkis } \\
53,4 \text { ir 52,3 m.), o individualistų amžiaus vidurkis } \\
46,5 \mathrm{~m} \text {. Skirtumų reikšmingumą patvirtina } \\
\text { ANOVA F kriterijus }\left(F=17, p=5.5 \cdot 10^{-8}\right)\end{array}$ \\
\hline $\begin{array}{l}\text { Hipoteze } H_{4} \text { : žmonių pajamos turi pri- } \\
\text { klausyti nuo to, kiek jie sukuria naudos } \\
\text { visuomenei }\end{array}$ & $\begin{array}{l}\text { Hipotezè pasitvirtino. Kad pajamos turi priklau- } \\
\text { syti nuo teikiamos naudos visuomenei, manė } \\
25,1 \text { proc. kolektyvistų ir } 17 \text { proc. individualistų. } \\
\text { Skirtumai reikšmingi (c2 }=23,4, \mathrm{p}=0,009)\end{array}$ \\
\hline $\begin{array}{l}\text { Hipoteze } H_{5} \text { : aukštesnių socialinių sluoks- } \\
\text { nių individai visuomenę mato labiau } \\
\text { harmoningą nei žemesnių sluoksnių }\end{array}$ & $\begin{array}{l}\text { Hipotezès atmesti negalima. Pagal sukuriamą } \\
\text { naudą visuomenei pajamas siūlè vertinti } 25 \text { proc. } \\
\text { verslininkų ir tik 9,1 proc. nekvalifikuotų darbi- } \\
\text { ninkų (c2 }=50,4, p=0,01)\end{array}$ \\
\hline $\begin{array}{l}\text { Hipoteze } H_{6}: \text { Labiau išsilavinę asmenys } \\
\text { pasisako už mažesnę turtinę diferenciaciją } \\
\text { (daugiau pilietiškumo) }\end{array}$ & $\begin{array}{l}\text { Ivertinus teiginio „Skirtumas tarp to, ką uždirba } \\
\text { Lietuvoje turtingi žmonès ir eiliniai piliečiai, yra } \\
\text { per daug didelis“ ir išsilavinimo ryší, hipotezę } \\
\text { teko atmesti. Skirtumo tarp išsilavinimo ir pajamų } \\
\text { skirtumo nenustatyta }\end{array}$ \\
\hline $\begin{array}{l}\text { Hipotezé } H_{7} \text { : moterys daugiau remia pa- } \\
\text { skirstymą ,pagal poreikị“ nei vyrai }\end{array}$ & $\begin{array}{l}\text { Kad žmonių pajamos turi priklausyti nuo to, ,kiek } \\
\text { šeimoje yra išlaikytinių (vaikų, neigaliujų)“, } \\
\text { pritare } 6 \text { proc. moterų ir } 4,2 \text { proc. vyrų. Skirtumai } \\
\text { statistiškai nereikšmingi }\end{array}$ \\
\hline
\end{tabular}




\begin{tabular}{|c|c|}
\hline $\begin{array}{l}\text { Hipoteze } H_{8} \text { : individualistai nori turèti in- } \\
\text { dividualią kontrolę sprendimo prièmimui }\end{array}$ & $\begin{array}{l}\text { Hipotezė pasitvirtino. Su teiginiu, kad „Manau, } \\
\text { kad priimti sprendimai yra sąžiningi ir teisingi tik } \\
\text { tada, kai juos priimant žmogus dalyvauja asme- } \\
\text { niškai“", sutiko } 59,5 \text { proc. kolektyvistų ir } 71 \text { proc. } \\
\text { individualistų Skirtumai statistiškai reikšmingi } \\
\left(\mathrm{c} 2=53,7, \mathrm{p}=8,5 \cdot 10^{-10}\right)\end{array}$ \\
\hline $\begin{array}{l}\text { Hipoteze } H_{9} \text { : jeigu individuali kolektyvisto } \\
\text { nuomone gali prieštarauti grupés tikslams, } \\
\text { jis jos neišsako }\end{array}$ & $\begin{array}{l}\text { Hipotezė iš dalies pasitvirtino. Teiginiui „Kokia } \\
\text { bebūtų problema, ją sprendžiant svarbiausia iš- } \\
\text { laikyti santarvę visuomenëje“ pritare } 55,8 \text { proc. } \\
\text { kolektyvistų ir po } 41,7 \text { proc. individualistų ir ne- } \\
\text { apsisprendusiujų. Skirtumai reikšmingi (c } 2=26,8 \text {, } \\
\mathrm{p}=0,00016)\end{array}$ \\
\hline
\end{tabular}

\section{Išvados}

1. Kaip atskleidè teorinè analizè, vartotojo vizija nesunkiai apibrèžiama ir nesukelia daug diskusijų, o pilietiškumo koncepcija yra daugiaplanė, nevienalytè ir net vidujai prieštaringa. Pažymètina, kad pilietiškumo kryptis, akcentuojanti individualizmą, iš esmès priartėjo prie rinkos ir vartotojo. Dèl piliečio sąvokos daugiaprasmiškumo empiriškai nagrinèjama ne piliečio ir vartotojo, o individualisto ir bendruomenès grupių (kolektyvisto) samprata.

2. Remiantis atlikta teorine analize ir bandomuoju tyrimu, buvo atrinkti teiginiai, kurie geriausiai diskriminuoja heterogeninę respondentų aibę pagal individualistinę ir kolektyvinę pozicijas. Taip buvo sudarytos trys aibès, kur išskirti reprezentatyvios apklausos respondentai suskirstyti į tris grupes. Didžiausią grupę sudarė individualistinių pažiūrų respondentai (44,4 proc.), antroje vietoje buvo tarpiniai respondentai (35,1 proc.), o mažiausia kolektyvistų aibè, kurią sudarè 20,5 proc. respondentų.

3. Iš suformuluotų devynių teorinių hipotezių empirinio tyrimo rezultatai patvirtino šešių hipotezių reikšmingumą. Šių hipotezių pagrindu išskirti būdingi kolektyvisto ir individualisto požiūriai ị socialinị teisingumą.

Kolektyvistui būdinga: vyresnis amžius; didesnis pasitikèjimas valdžia ir makrolygmens perskirstymu nei individualistui; didesnis pasitikèjimas makrolygmens teisingumu nei rinkos teisingumu; sprendžiant problemas prioritetas teikiamas santarvès visuomeneje išlaikymui (tam pritarè 55,8 proc. kolektyvistų)

Individualistui būdinga: Prioritetas - individuali kontrolè sprendimo prièmimui. Net 71 proc. šios aibès atstovų pritarè teiginiui, kad priimti sprendimai yra sąžiningi ir teisingi tik tada, kai juos priimant žmogus dalyvauja asmeniškai; jaunesnis amžius: kolektyvistų amžiaus vidurkis 53,4, individualistų - 46,5 metų. Manoma, kad pajamos turi būti susietos su darbu, o ne su nauda visuomenei (tik 17 proc. individualistų manè, kad pajamos turi priklausyti nuo teikiamos naudos visuomenei).

4. Pažymėtina, kad aukštesnių socialinių sluoksnių asmenys skirtingai vertina veiksnius, nuo kurių turi priklausyti žmonių pajamos, nei žemesnių visuomenės sluoks- 
nių atstovai. 35 proc. verslininkų, 44 proc. aukščiausios ar vidutinės grandies vadovų ir 42,9 proc. ūkininkų svarbiausiu veiksniu, nuo kurio turi priklausyti pajamos, pasirinko gebejjimų lavinimą ir kvalifikacijos kèlimą. Tuo tarpu kad pajamos turi priklausyti nuo to, „kaip sunkiai ir daug asmuo dirba“, pasirinko 39,3 proc. kvalifikuotų darbininkų, 52,3 proc. nekvalifikuotų darbininkų.

5. Tyrimas patvirtino socialinio teisingumo ir visuomenès išsilavinimo problemas. Vertinant priežastis, dèl kurių Lietuvoje žmonės tampa turtingi, net 45,1 proc. respondentų atsakè, kad turtingais tampama dẻl „Nesąžiningų susitarimų ir korupcijos“, o 18,5 proc. - „Dèka palankaus likimo ir jiems tinkamai susiklosčiusių aplinkybių“. Tik 2,5 proc. respondentų nuomone, turtingais tampama „Dèl gero išsilavinimo“.

\section{Literatūra}

Abbott, L. F. Theories of industrial modernization and enterprise development: $A$ review of the social science literature. New Ypok: Industrial Systems research Publications, 1983.

Baudrillard, J. Vartotoju visuomene. Kaunas: Kitos knygos, 2010.

Bodo, Lippl. Justice Ideologies, Income-Justice, and the Welfare State: A Comparison of Justice Ideologies and the Perceived Justice of Income in the United States, West Germany, and the Netherlands (ISJPArbeitsbericht No. 47). Berlin: HumboldtUniversitaet, 1998.

Bernotas, D.; Guogis, A. Development of social security in Lithuania: achievements and drawbacks. Forum Bosnae. Sarajevo: Medunarodni forum Bosna, 2012, 55, 150165.

Burinskiene, M.; Rudzkiene, V. Assessment of sustainable development in transition. Ekologija. 2007, 53: 27-33.

Choi, J. Outcome Favorability, Procedures, and Individualism-Collectivism in Procedural Justice perceptions. Seoul Journal of business. 2003, 9 (1): 1-26.

Cogan, J. D.; Grossman, D.; Lui, M. Citizenship: The democratic imagination in a global local context. Social Education. 2000, 64 (1): 48-52.

Cohen, J. Changing paradigms of citizenship and the exclusiveness of the demos. International Sociology. 1999, 14(3): 245268.
Colquitt, J. A.; Conlon, D. E.; Wesson, M. J.; Porter, Ch. O. L. H.; Ng, K. Yee. Justice at the millennium: A meta-analytic review of 25 years of organizational justice research. Journal of Applied Psychology. 2001, 86 (3): 425-445.

Dromantienè, L. Socialinès Europos kūrimas. Vilnius: Mykolo Romerio universitetas, 2008.

Earlye, P. C.; Gibson, C. B. Taking stock in our progress on individualism-collectivism: 100 years of solidarity and community. Jounal of Management. 1998, 24: 265-304.

Esping-Andersen, G. Three Worlds of Welfare Capitalism. Cambridge: Polity Press, 1990.

Faulks, K. Citizenship. London: Routledge, 2000.

Feldman, S. A Conflicted Public? Equality, fairness, and Redistribution [interaktyvus]. 2003 [žiūrèta 2013-01-10]. <http://www. princeton.edu/csdp/events/Inequality2003/ feldman.pdf $>$.

Frohlich, N.; Oppenheimer, J. A. Values, Policies, and Citizen Competence: An Experimental Perspective. Citizen Competence and Democratic Institutions (Elkin, S. L.; Soltan, K. E. eds.). The Pennsylvania State Univ. Press, 1999, p. 161-187.

Gilbert, N. Transformation of the Welfare State: The Silent Surrender of Public Responsibility. New York: Oxford University Press, 2002. 
Hogg, M. A.; Vaughan, G. M. Social Psychology. Harlow: Prentice Hall, 2002.

Juknevičius, S. Skirtingumo dimensijos: Lietuvos gyventoju vertybès europiniame kontekste. Vilnius: Gervele, 2002.

Kovel, J. The Enemy of Nature: The End of Capitalism or the End of the World? Second Editon, 2007.

Lane, R. Market justice, Political Justice. American Political Science Review. 1986, 80: 383-402.

Lewin-Epstein, N.; Kaplan, A.; Levanon, A. Distributive Justice and Attitudes Toward the Welfare State. Social Justice Research. 2003, 16 (1).

Mann, M. Ruling class strategies and citizenship. Sociology. 1987, 21(3): 339-354.

Markus, H. R.; Kitayama, S. Culture and the self: Implications for cognition, emotion, and motivation. Psychological Review. 1991, 98: 224- 253.

Marshall, G.; Swift, A.; Routh, D.; Burgoyne, C. What Is ans What Ought to Be: Popular Beliefs About Distributive Justice in Thirteen Countries. European Sociological Review. 1999, 15: 349-367.

Marshall, T. H. Class, citizenship, and social development. Westport, Conn., Greenwood Press, 1973.

Maslow, A. Psichologiniai duomenys ir vertybių problema. Gerrio kontūrai. XX a. užsienio etika. Vilnius: Mintis, 1989.

Oldfield, A. Citizenship and Community: Civic Republican and the Modern World. London: Routledge, 1990.
Rokeach, M. The Nature of Human Values. New York: Free Press, 1973.

Schwartz, S. H. Value orientations: Measurement, antecedents and consequences across nations. Jowell, R.; Roberts, C.; Fitzgerald, R.; Eva, G. (Eds.). Measuring attitudes cross-nationally lessons from the European Social Survey. London: Sage, 2006.

Sor-Hoon, Tan. Challenging CitizenshipGroup Membership And Cultural Identity In A Global Age. Ashgate Pub Ltd, 2005.

Steenberg, B. van ed. The condition of citizenship. London: Sage Publications, 1994.

Stenberg, R. Cognitive Psychology, second edition. Fort Worth: Harcourt Brace College Publishers, 1999.

Suhay, E. A. Group Influence ans American Ideals: How Social Identity and Emotrion Shape Our Political Values and Attitudes. Doctoral Dissertation. University of Michigan, Ann Arbor, MI, 2008.

Turner, B. S. Citizenship studies: a general theory. Citizenship studies. 1997, 1(1): 5-18.

Turner, B. S. Civility, civil sphere and citizenship: solidarity versus the enclave society. Citizenship studies. 2008, 12 (2): 177-184.

Weber, M. The Protestant ethic and the spirit of capitalism (T. Parsons, trans.). New York: Charles Scribner's Sons (Original work published as two separate essays, 1904190).

\title{
SOCIAL JUSTICE PERCEPTION: CITIZENS AND CONSUMERS APPROACH
}

\author{
Vitalija Rudzkienè, Miglè Černikovaitè \\ Mykolas Romeris University, Lithuania
}

Summary. The changes in modern welfare states engendered by globalization, social needs and environmental issues evoke the question of the social bases of support of the modern welfare state system. Although socially just sustainable society is the main value and the 
general purpose of social development, the concept of a model for the ideal society accepted by some groups of different ideologies and different levels of development significantly differs. The research on social values in the scientific literature indicates the two social groups, citizens and consumers, having the sharpest contrasts in social value systems. This difference between these groups derives from two distinct ideologies and distinct value systems. By searching for the answer how the differences of these groups impact the perception of social justice values, which is crucial for a long term socio-economic development, the authors developed a theoretical framework, which outlines the structural relationship between the social attributes, principles of justice and individual preferences. Using data from a recent representative populationbased survey on attitudes about social justice, conducted in Lithuania in $2013(N=1050)$, the authors of the article tested a number of assumptions and theoretical hypothesis. The findings revealed three different sets of respondents with distinct value preferences and collectivistic attitudes. The authors also found that these groups have significant differences not only in evaluating the factors that determine the income of the people, but also in the trust in government, participation in decision making, etc. The results allowed to distinguish characteristic features and social justice attitudes of the groups and to create the attribute sets.

Prepared according to the scientific project financed by LSC SIN-12005 "Guidelines for Forming Social Justice Perception of Citizens and Customers".

Keywords: perceived social justice, social values, social groups, citizens, customers, value diversity.

\section{JEL classification:}

D63 - Equity, Justice, Inequality ant other nominal criteria and measures.

Vitalija Rudzkienė, Mykolo Romerio universiteto Ekonomikos ir verslo instituto profesorè. Mokslinių tyrimų kryptys: socialiniai tyrimai, darnios plètros modeliai, socialinès vertybès.

Vitalija Rudzkienė, Mykolas Romeris University, Institute of Economics and Business, Professor. Research interests: social research, sustainable development models, social values.

Miglė Černikovaitė, Mykolo Romerio universiteto Ekonomikos ir verslo instituto doktorantė. Mokslinių tyrimų kryptys: rinkos tyrimai, socialinis marketingas, vertybès.

Miglė Černikovaitė, Mykolas Romeris University, Institute of Economics and Business, Doctoral Student. Research interests: marketing research, social marketing, social values. 